\title{
Foraging Habits of Aerial Insectivores in the Coastal Region of Raigad, Maharashtra
}

\section{Jayesh Patil', Dhanusha Kawalkar², Shirish Manchi $^{2 *}$}

1Department of Biodiversity, Wildlife Conservation, and Management, B. N. Bandodkar College, Thane, Maharashtra400601

2Division of Conservation Ecology, Sàlim Ali Centre for Ornithology and Natural History, Anaikatty Post, Coimbatore Tamil Nadu-641108

\section{Study Area: Raigad, India \\ Coordinates: $\left(17^{\circ} 51^{\prime}-19^{\circ} 80^{\prime} \mathrm{N}, 72^{\circ} 51^{\prime}-73^{\circ} 40^{\prime} \mathrm{E}\right.$}

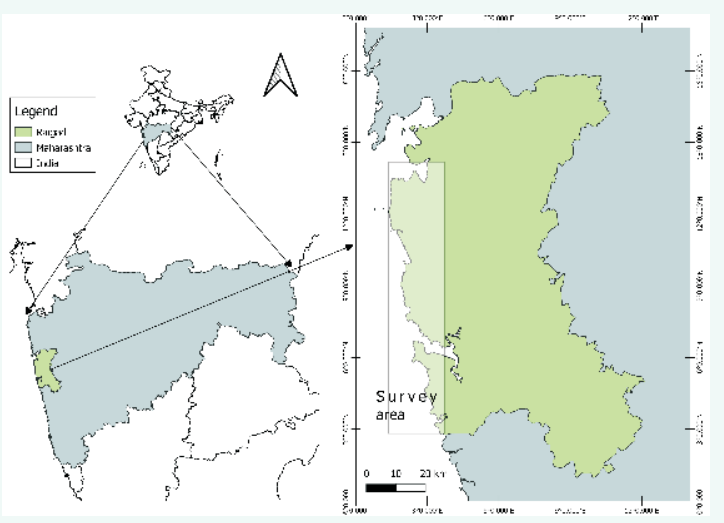

Keywords: Guild, foraging ecology, Swallow, Swift Introduction:

What an animal feeds on? Is an essential component of understanding many ecological issues, including energy flow, competition, and adaptation. Foraging behaviour is crucial for an animal's survival (Kilpatrick et al., 2020) and thus, forms a central concern of ecology (Kamil et al., 1987). Foraging depends primarily on the food resources' availability influencing the abundance, distribution, and habitat suitability (Adamik et al. 2003).

In birds, food selection and feeding strategies determine the guild of a particular species. The ecology and evolution of bird communities are the basis of their dietary adaptations (Cody \& Diamond, 1975). These dietary preferences can be broadly quantified into an ecological niche that represents the diet of a bird species. In the bird community or taxonomical group, a more acceptable classification as the subset of the niche is called the guild. The guild concept was applied to the different groups of species in various fields of study (Root, 1967; Simberloff \& Dayan 1991). The knowledge of guilds can explain the

\section{Abstract}

The present study aims to understand the foraging habitat and assemblages of the aerial insectivores in the coastal Raigad district, Maharashtra. The study was conducted in the five coastal talukas of Raigad District; (1) Alibag, (2) Roha, (3) Murud, (4) Mhasla, and (5) Shrivardhan. The random survey was conducted in the study sites using vehicles and motorized dugout dingies looking for the birds feeding on the aerial insects between 0600 and 1800 hours. Total five species were recorded during the survey, namely; Little Swift (LS) (Apus affinis), Asian Palm Swift (APS) (Cypsiurus balasiensis), Barn Swallow (BS) (Hirundo rustica), Wire-tailed Swallow (WTS) (Hirundo smithii), and Dusky Crag Martin (DCM) (Ptyonoprogne concolor). All the species were distributed throughout the coastal region of Raigad. APS was the most abundant and widely distributed among all the aerial foragers, whereas the WTS was the least encountered during the survey. The encountered species were distributed in different habitats. However, all the species were active over the deciduous forest. We also observed assemblages of APS and BS whereas, DCM and WTS forage only within the species group. We recommend a further detailed study to understand the foraging ecology of aerial insectivores in coastal and inland regions of Maharashtra.

relationship between bird communities and habitats (Verner, 1984). Avian dietary guild and species richness differ in latitudinal, environmental, and biogeographic variations (Primack \& Corlett 2005). Guild classification of various species is associated with specific food resources and specific feeding strategies. Based on their feeding guild, the birds are categorized as herbivores, granivores, frugivores, nectarivores, aerial insectivores, terrestrial insectivores, carnivores, scavengers, and omnivores.

Among insectivores, aerial insectivores are comprised of the birds, while flying, feed on insects. Swifts, swiftlets, treeswifts, swallows, and martins are some of the known aerial insectivores. The aerial insectivores are distributed worldwide, in all the biogeographic zones and all the possible habitats known. The members of Apodidae and Hirudinidae use similar habitats. Swifts and swiftlets are colonial bird species that nest together in big colonies where the Treeswift, swallows, and martins have dispersed nesting (Waugh, 1978). These species are aerial foragers and are often seen in mixed flocks (Snapp,1976). While foraging

*Corresponding Author: ediblenest@gmail.com 
in mixed flocks, these birds hunt the insects at different heights to reduce the competition and avoid niche overlap (Wiens, 1989). The niche overlap depends on the resource, whether they are abundant (Gonzalez-Solis et al., 1997). Hence, it is essential to study the diet and niche overlap to understand the species' co-occurrence with a similar ecological and morphological feature (Gonzalez-Solis et al., 1997; Garcia \& Arroyo, 2005).

Aerial insectivore is the least studied guild of birds in India. India has around 34 known aerial insectivorous birds (Grimmett et al., 2014). Amongst all the aerial insectivores, swiftlets (family- Apodidae) in the Andaman and Nicobar Islands are the only ones that received attention from the researchers. Plume-toed Swiftlet (PTS) (Collocalia affinis) and the Edible-nest Swiftlet (ENS) (Aerodramus fuciphagus inexpectatus) are restricted to the Andaman and Nicobar Islands in the Indian Territory (Sankaran \& Manchi, 2008; Grimmett et al., 2014). Recently, foraging habits and habitats of PTS and the ENS are well documented from the Andaman Islands (Manchi \& Sankaran, 2010). This study indicated that swiftlet foraging habits vary temporally and seasonally and might be in response to change in the food supply. This study was conducted to contribute towards the conservation of the Edible-nest Swiftlet in the Islands. No other Indian studies attempted to understand the other aerial insectivores in such details, even though we have species like Indian swiftlet (Aerodramous unicolor) and Dark rumped swift (Apus acuticauda) with national and international conservation importance. Knowing the lack of knowledge regarding aerial insectivores in mainland India, the present study was conducted as part of the larger project concerning the conservation of the Indian Swiftlet in the Western Ghats of Maharashtra. Indian Swiftlet is believed to be under threat by anthropogenic interference and therefore included in the Schedule-I of Indian Wildlife (Protection) Act, 1972. The discussed study aimed to understand the diversity, distribution, and foraging habitats of the aerial insectivores in the coastal regions of the Raigad district of Maharashtra. As the region has earlier records of roosting and foraging Indian Swiftlet, the study was conducted to understand the other aerial insectivores competing with the Indian Swiftlet in terms of the foraging habitat. The study's outcome was expected to contribute towards strategizing the conservation measures for the Indian Swiftlet.

\section{Methodology:}

Study region: The population of the Indian Swiftlet is known to be restricted to the coastal regions in Maharashtra (Mahabal et al., 2007). Therefore the present study was conducted in the coastal regions of the Raigad district, Maharashtra. Raigad, previously known as Kolaba, is one of the districts in the Konkan Division of Maharashtra with the Arabian Sea coast as its western boundary. Most hilly places of the district are in the Sahyadri mountain range of the Northern Western Ghats of India. Raigad is divided into 15 tehsils, namely Uran, Panvel, Karjat, Khalapur, Pen, Alibag, Murud, Roha, Tala, Sudhagad, Mangaon, Shrivardhan, Mhasla, Mahad, and Poladpur (Refer-Map).

The district's climate is typical of that on India's west coast, with plentiful, regular, and seasonal rainfall during the monsoon season. Being a coastal district, the diurnal and seasonal variations in temperature is comparatively less. The southwest monsoon commences by June and continues till the beginning of October, with an average annual rainfall of $3028.9 \mathrm{~mm}$. Nearly $95 \%$ of the annual rainfall is received during the South-West monsoon season. The relative humidity is, on average, over $80 \%$ during the South-West monsoon season. In the rest of the year, the relative humidity is between 65 to $75 \%$.

The district's geology consists of dark-coloured volcanic lava flows and laterites dating back to the Mesozoic Era. These are spread out in horizontal sheets or beds and have innumerable spurs, hills, ridges, peaks, and plateau; the lava is called plateau basalts. Since these basaltic lava flows cover a vast region in the Deccan and frequently present a step-like appearance to the hills and ridges, they are commonly known as the "Deccan trap." Deccan trap is mainly Basaltic. On the hill slopes, the soil is generally shallow but moderately fertile and deep in valleys. In the narrower belts along the coastline, the soil is rich alluvial with an adequate supply of water (Narkhede, 2011).

Data collection: all the observations included in the study were between 2oth February 2020 and 11th March 2020. The data was collected from the coastal places of Raigad District, (1) Alibag, (2) Roha, (3) Murud, (4) Mhasla, and (5) Shrivardhan. The sampling area was randomly searched for the aerial insectivorous birds. The study area was surveyed using vehicles (two and four-wheelers) and motorized dugout dingy. The survey was conducted along the roads and pathways on mainland India and the approachable offshore islands between 0600 hours and 1800 hours when these diurnal foragers are active. The binocular (Model: Nikon Monarch 10×42) and a digital camera (Model: Nikon Cool Pix P9oo) were used to observe the foraging birds (in flight) and have photographic documentation for the species identification, whenever required. Various species in the foraging flock were identified using the field guide (Grimmett et al., 2014). At every location, the information on (1) the number of species, (2) the number of individuals/species, and (c) the type of foraging habitat was noted. The foraging habitats were divided into six classes, 1) Deciduous forest, 2) Mangroves, 3) Coastline (on the beach), 4) Rural areas, 5) Urban areas, and 6) Plantations. The foraging areas' latitude and longitude were recorded using GPS (Model: Garmin Montana 680). These locations were later included in the base map to understand the 
species' distribution.

The percentage frequency and abundance of each species encountered during the study were estimated. To understand the species' assemblage pattern, we used a cooccurrence type of Agglomerative Hierarchical Analysis to obtain a dendrogram. All the analysis was done using XLSTAT software (Addinsoft; https://www.xlstat.com). Further, the species encounter data was also segregated as per the habitat categories to understand how various species are using different habitats. SPSS ver. 2016 (IBM Corp 2016) was used to build charts.

\section{Findings:}

Of the 34 and 11 aerial insectivores known from India and Maharashtra, respectively, we encountered five species during the present study; Little Swift (LS) (Apus affinis), Asian Palm Swift (APS) (Cypsiurus balasiensis), Barn Swallow (BS) (Hirundo rustica), Wire-tailed Swallow (WTS) (Hirundo smithii), and Dusky Crag Martin (DCM) (Ptyonoprogne concolor). The other aerial insectivores known from the Western Ghats of Maharashtra are Indian Swiftlet (IS) (Aerodramus unicolor), Alpine Swift (AS) (Apus melba), Crested Treeswift (Hemiprocne coronata), Ashy Woodswallow (Artamus fuscus), Red-rumped Swallow (Cecropis daurica), Streak-throated Swallow (Petrochelidonfluvicola).

All the encountered species $(n=5)$ are known residents of the region and distributed across the survey area (Fig.-1). These known colonial foragers were observed forging in various flock sizes ( $n=35,49 \pm 45$ individuals/flock). Except for the WTS, all the other four species have distribution across the study area. Amongst all the encountered aerial insectivores, the APS was the most abundant $(7.68 \pm 8.44$ encounters/location; Table-1), whereas DCM (4.67 \pm 2.52 encounter/location) and WTS (1.67 \pm 2.12 encounter/ location) were least abundant.

Table-1: Number of individuals, percent frequency, and abundance of the aerial insectivores encountered in the study area

\begin{tabular}{llccc}
\hline$\#$ & Species & $\mathrm{N}$ & $\% \mathrm{fr}$. & $\mathrm{Abu}$. \\
\hline 1 & $\begin{array}{l}\text { LittleSwlft } \\
\text { (Apus affinis) }\end{array}$ & 198 & 34.32 & 0.34 \\
2 & $\begin{array}{l}\text { Asian-Palm Swift } \\
\text { (Cypsiurus balasiensis) }\end{array}$ & 238 & 41.25 & 0.41 \\
3 & $\begin{array}{l}\text { Barn Swallow } \\
\text { (Hirundo rustica) }\end{array}$ & 122 & 21.14 & 0.21 \\
$4 \begin{array}{l}\text { Wire-tailed Swallow } \\
\text { (Hirundo smithii) }\end{array}$ & 5 & 0.87 & 0.01 \\
5 & $\begin{array}{l}\text { Dusky-CragMartin } \\
\text { (Ptyonoprogneconcolor) }\end{array}$ & 14 & 2.43 & 0.02 \\
\hline
\end{tabular}

$\mathrm{N}=$ Number of individuals encountered; $\% \mathrm{fr} .=\%$ frequency of individual; $\mathrm{Abu}$. =Abundance (encounters/location)

The APS and BS occurred in all the surveyed habitat types whereas, LS was confined to rural, shoreline, and

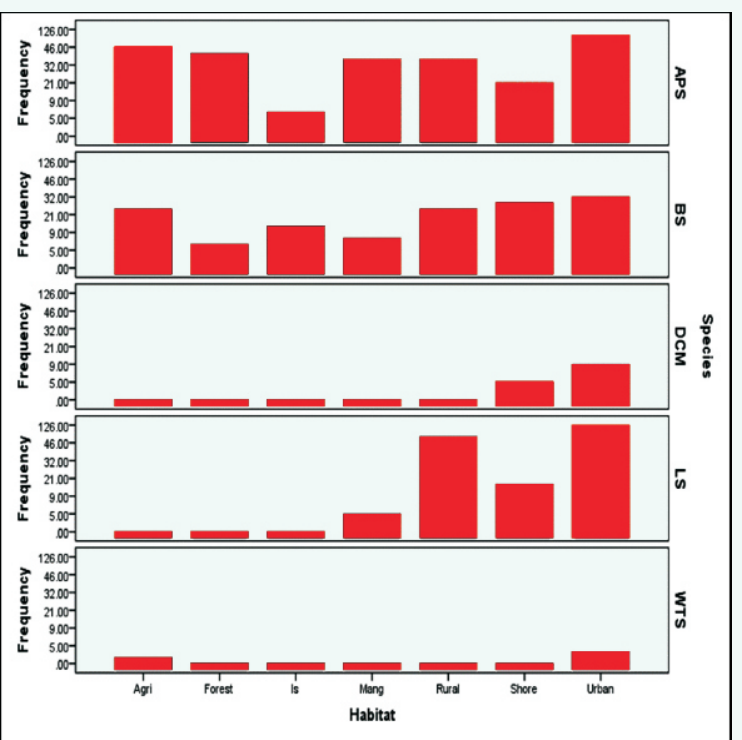

Figure-1. The occurrence of different aerial insectivore species in various habitats of the study area

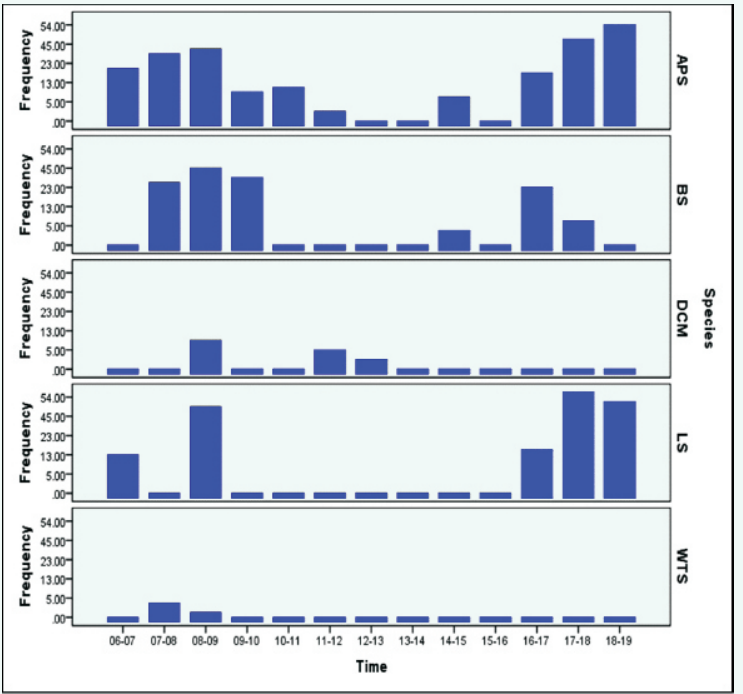

Figure-2: Temporal variations in the activity of the aerial insectivores encountered in the study area.

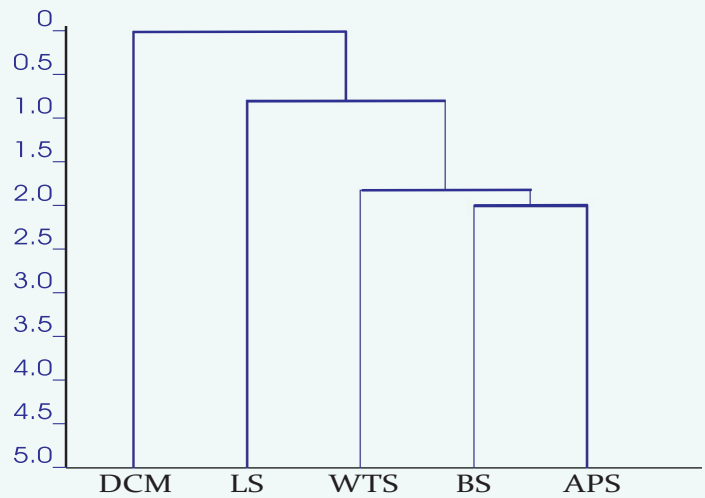

Figure-3: Dendrogram of the foraging assemblages recorded during the survey. 
urban areas. We could sight WTS just three times, once in the agricultural land and twice in the urban area, perched on the high tension electric wires (Map).

The different aerial foragers' foraging activity was in the specific time slots during the day (Fig.-2). The highest foraging activity was seen during the 0700 to $0900 \mathrm{hrs}$ in the morning and 1700 to 1900 hrs in the evening. The LS, APS, and BS were active throughout the day, whereas WTS was mostly sighted during $0700-0800 \mathrm{hrs}$. The foraging activity of DCM increased during morning hours (o80o-09oo hrs) and was minimal between 1100-1300 hrs.

The dendrogram shows that APS, BS, and WTS forage together. During the survey, few times 1-2 LS individuals were also recorded foraging with APS and BS. Of all the encountered species, DCM has always seen feeding alone (Fig.-3).

\section{Discussion:}

The swifts, swallows, and martins are consistent and opportunistic aerial foragers (Norberg, 1986), which take a wide variety of prey types (Collins, 2015). Amongst the five encountered aerial insectivores, the APS was the most abundant but was not most common at all the sites. The species is highly gregarious and forages in flocks of 40 to $=$ 1000 individuals (Chantler \& Boesman, 2020a). We understand that the APS's high encounter might be an outcome of the easy availability of the breeding habitat in terms of the coconut (Cocos nucifera) and areca nut (Areca catechu) plantations in the Raigad District's coastal regions. The species primarily depends on the fan palms and uses thatched roofs as nesting and roosting sites. It forages adjacent to mangroves and paddy (Chantler \& Boesman, 2020a). This specific APS foraging location also explains most species' encounters in the urban and agricultural habitats (Fig.-1). Furthermore, the APS's patchy occurrence, near their roosting and breeding sites, throughout the day, adds to most encounters of the species. The LS was locally the most common aerial insectivore; however, it was not the most abundant (Table- 1) This gregarious species is known to occur over a wide range of habitats and latitudes. It commonly forages with other Apodids. As the species is well adapted to breed under human constructions, its high encounters in the urban and rural areas are apparent, as described by Chantler and Boesman (2020b) In the study area, the LS was active throughout the day, though most active during the evening hours (Fig- 2 ) During the survey, the LS in the study area were raising the nestlings $(n=3$ breeding colonies with 102 nests) Swifts and swiftlets forage close to their breeding sites while incubating eggs and raising chicks (Medway, 1962; Manchi, 2009; Chantler \& Boesman, 2020b) It might be the reason to have them in a significant number, wherever encountered, near their breeding sites.

On a global scale, the BS is common and widespread
(Brown \&Brown, 2020) The BS had a wide distribution across the study area, but these species were less abundant (8.71 6.81 encounters/location). The comparatively less abundance of BS in the region might be an outcome of the survey season as the species is known to breed between March and May. As per Brown \& Brown (2020) the BS generally forages individually or in a pair during the breeding season. They usually feed near meadows, wetlands, and fields (Snapp, 1976) The BS is also known to feed on insects attracted to lights during dusk hours (Fig. -4 ; Brown \& Brown 2020) The BS was found more active in the urban area, near the shore, and rural habitats (Fig. 1) , probably because of suitable foraging and breeding habitats.

Amongst all the encountered species, DCM and WTS were the aerial insectivores with the least abundance (Table- 1) It is presently difficult to comment on the low frequency of encounters, as the survey period and frequency were minimal. However, as Turner (2020b) described, WTS was more active in urban, agricultural, and forest areas (Fig. 1) DCM often flying low (4? $5 \mathrm{~m}$ from the ground) and predominantly over streams, cultivation and, human habitations (Turner, 2020b) and also, DCM is usually expected close to its breeding sites. This habit of the DCM indicates the presence of its breeding sites near the shoreline and urban areas.

The swifts (APS and LS) and the BS were active throughout the day whereas, WTS was mostly sighted during early morning hrs (o700- o9oo hrs) .Similarly, DCM was active during $0800-0900$ hrs, and the foraging activity was minimal between $1100-1300$ hrs. Lack and Owen (1955) reported that the abundance of airborne insects depends on weather conditions, specifically abundant during the afternoon (after $1430 \mathrm{hrs}$ ) in all weathers. In poor weather, the abundance increase during 1600- 1700 hrs and 1100- 1200 hrs in fine weather. Hence, the time during the day and habitat can be varied for different species and is directly affected by the local weather conditions (Lack \& Owen 1955) .The weather conditions and breeding seasonality also influence foraging habits in swiftlets (Medway, 1962; Langham, 1980; Nguyen, 1983; Lim \& Cranbrook 2002; Nguyen et al. 2002; Manchi \& Sankaran, 2010) .

The most frequently recorded assemblage comprised APS, BS, and WTS; however, DCM was always encountered foraging in isolation. WTS usually forage in pairs or small groups in a mixed flock with other swallows and swifts (Apodidae); but, no such behaviour was encountered during the present study. In contrast to our finding, Møller (2001) and Cramp (1988) separately have recorded assemblages of Common Swift Apus apus, Barn Swallow Hirundo rustica, and House Martin Delichon urbicum from the western Palearctic region. Swifts and swallows have an altitudinal foraging range overlap; hence, form an 
assemblage (Norberg, 1986). On the contrary, a few studies (Norberg, 1986; Kopij, 200o; Collins, 2015) show the differences in their feeding habitats, which create a niche and altitudinal partition. The swifts (APS and LS) usually were not observed together. A few studies suggest (Lack \& Owen, 1955; Orlowski \& Karg, 2013) that this happens when co-occurring swift species compete for food leading to patch and prey specialization (Waugh, 1978).

The present study attempted to understand the habitats and assemblages of the foraging aerial insectivorous in the Raigad district's coastal regions. As this short study was restricted to the coastal areas, only five aerial insectivores could be recorded. These species were encountered foraging at different times of the day; hence we infer that the foraging activity's temporal variations help these species avoid competition and foraging habitat overlap. Out of the seven identified habitat types, the deciduous forest was used by all the aerial insectivores, indicating the importance of this particular habitat for the existence of these birds with a special guild. Further detailed surveys (both in the coastal area and inland) will help better document aerial insectivores in the Raigad district. Moreover, detailed studies on the birds' diet can provide insight into the foraging habitat selection by these species.

\section{Acknowledgements:}

We thank the Ministry of Environment, Forest and Climate Change (MoEF\&CC), Government of India for funding the Indian swiftlet conservation program under which the study was conducted. We are also grateful to the Maharashtra state forest department for providing us with the required permissions. This study wouldn't have been possible without the field assistance of Akshay Gharat and Jitesh Gharat.

\section{References:}

Adamik, P., Kornan, M. \& Vojtek, J. (2003): The effect of habitat structure on guild patterns and the foraging strategies of insectivorous birds in forests. Biologia, 58:275-285.

Brown, M.B. \& Brown, C.R. (2020): Barn Swallow (Hirundo rustica), version 1.o. In: Birds of the World (P. G. Rodewald, Ed.). Pub. by: Cornell Lab of Ornithology, Ithaca, NY, USA.

Chantler, P. \& Boesman, P.F.D. (2020a): Asian Palm-Swift (Cypsiurus balasiensis), version 1.o. In: Birds of the World (J. del Hoyo, A. Elliott, J. Sargatal, D. A. Christie, and E. de Juana, Eds,). Pub. by: Cornell Lab of Ornithology, Ithaca, NY, USA.

Chantler, P. \& Boesman, P.F.D. (202ob): Little Swift (Apus affinis), version 1.o. In: Birds of the World (J. del Hoyo, A. Elliott, J. Sargatal, D. A. Christie, and E. de Juana, Eds.). Pub. by: Cornell Lab of Ornithology, Ithaca, NY, USA.

Cody M.L. \& Diamond, J.M. (1975): Ecology and Evolution of Communities. Pub. by: Harvard University Press, Cambridge, MA.

Collins, C.T. (2015): Food habits and resource partitioning in a guild of Neotropical swifts. Wilson J. Ornithol., 127(2):239-248.

Cramp, S. (1988): The Birds of the Western Palaearctic
(Volume. 5). Pub. By: Oxford University Press, Oxford, UK.

Garcia, J.T. \& Arroyo, B.T. (2005): Food niche differentiation in sympatric Hen Circus cyaneus and Montagu's Harriers Circus

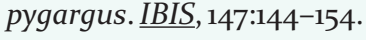

Gonzalez-Solis, J., Oro, D., Jover, L., Ruiz, X. \& Pedrocchi, V. (1997): Trophic niche width and overlap of two sympatric gulls in the Southwestern Mediterranean. Oecologia, 112:75-80.

Grimmett, R., Inskipp, C. \& Inskipp, T. (2014): Birds of the Indian Subcontinent. Pub. by: Oxford publishers.

Holmes, R.T., Schultz, J.C. \& Nothnagle, P. (1979): Bird predation on forest insects: an exclosure experiment. Science, 206:462-463.

IBM Corp. Released. (2016): IBM SPSS Statistics for Windows, Version 24.o. Armonk, NY: IBM Corp.

Kamil, A.C., Krebs, J.R. \& Pulliam, H.R. (1987): Foraging Behavior. Pub. by: Plenum press, New York and London. Pp.5

Kilpatrick, Z.P., Davidson, J.D. \& Hady, A.D. (2020): Normative theory of patch foraging decisions. bioRxiv preprint.

Lim, C.K. \& Earl of Cranbrook. (2002): Swiftlets of Borneo: Builders of Edible Nests. Pub. by: Natural History Publication, Kota Kinabalu, Borneo.

Kopij, G. (200o): Diet of swifts (Apodidae) and swallows (Hirundinidae) during the breeding season in South African grassland. Acta Ornithol., 35:203-206.

Lack, D. \& Owen, D.F. (1955): The food of the swift. L. Anim. Ecol., 24:120-136.

Langham, N. (1980): Breeding Biology of the Edible-nest Swiftlet (Collocalia fuciphaga). IBIS, 122:447-461.

Mahabal, A., Pande. S., Sharma, R.M. \& Pednekar, S.N. (2007): Status Survey of Endangered Species, Status Survey of Indian Edible-nest Swiftlet Collocalia unicolor (Jerdon) in the Western Ghats, West Coast and Island in the Arabian Sea, India. 52 p. Pub. by: Zoological Survey of India, Kolkata, W.B.

Manchi, S.S. \& Sankaran, R. (2010): Foraging habits and habitat use by Edible-nest and Glossy swiftlets in the Andaman Islands, India. Wilson J. Ornithol., 122(2):259-272.

Medway, L. (1962): The swiftlets (Collocalia) of Niah Cave, Sarwak. Part 2. Ecology and regulation of breeding biology. $\underline{I B I S}$, 104:228-245.

Moller, A.P. (2001): The effect of dairy farming on barn swallow Hirundo rustica abundance, distribution, and reproduction. I App. Ecol., 38:378-389.

Morse, D.H. (1971): The foraging of warblers isolated on small islands. Ecology, 52:2.

Narkhede, D.S. (2011): Agricultural Landuse and Land Degredation in Raigad District (Maharashtra)-A Geographical Prespective. Ph. D. Thesis, submitted to: Shivaji University, Kolhapur, India.

Nguyên, Q.P., Quang, Y .\& Voisin, J.F. (2002): The White-Nest Swiftlet and the Black-Nest Swiftlet: A Monograph: with Special Reference to Vietnamese Populations. Pub. by: Society Nouvelle des Editions Boubee, Paris.

Norberg, U.M. (1986): Evolutionary convergence in foraging niche and flight morphology in insectivorous Aerial-Hawking Birds and Bats. Ornis Scand, 17(3):253-260. 
Orlowski, G. \& Karg, J. (2013): Diet breadth and overlap in three sympatric aerial insectivorous birds at the same location. $\underline{\text { Bird }}$ Stud., 6o(4), 475-483.

Primack, R. \& Corlett R. (2005): Tropical Rain Forests: an Ecological and Biogeographical Comparison. Pub. by: Blackwell Publishing, Malden, MA.

Ricklefs, R.E. (1979): Ecology. Pub. by: Chiron Press, New York.

Root, R.B. (1967): The niche exploitation pattern of the Blue-gray Gnatcatcher. Ecol. Monogr., 37:317-335.

Royama, T. (1969): Factors governing the hunting behavior and selection of food by the great tit (Parus major L). L. Ani. Ecol., 39: 619-668.

Rajashekara, S. \& Venkatesha, M.G. (2014): Eco-spatial and temporal variation in waterbirds composition and their relationship with habitat characteristics of urban lakes of Bengaluru city, India. L.Adv. Res., 2(7):6o-8o.

Sankaran, R. \& Manchi, S. (2008): Conservation of the Ediblenest Swiftlets in the Andaman and Nicobar Islands. Occasional Report. Sàlim Ali Centre for Ornithology and Natural History, Coimbatore, India.

Simberloff, D. \& Dayan, T. (1991): The guild concept and the structure of ecological communities. Ann. Rev. Ecol. Systemat., 22:115-143.
Snapp, B.D. (1976): Colonial breeding in the Barn Swallow (Hirundo rustica) and its adaptive significance. Condor. 